\title{
The Political Economy of Climate Resilient Development Planning in Bangladesh
}

\author{
Khurshid Alam, Md Shamsuddoha, Thomas Tanner, Moshahida \\ Sultana, Muhammad Jahedul Huq and Sumaiya S. Kabir*
}

\begin{abstract}
Following three major disasters in 2007, Bangladesh intensified its effort to tackle climate change through development of the Bangladesh Climate Change Strategy and Action Plan (BCCSAP). The process of plan formulation led to debates nationally and internationally regarding the financing and integration of climate change into development planning. Using a political economic lens, this article illustrates how major national initiatives around international problems must be understood in terms of the interplay of actors, their ideas and power relations. The article argues that: (i) Power relations among actors significantly influenced the selection of ideas and implementation activities; (ii) Donor concerns around aid effectiveness and consequent creation of parallel mechanisms of planning and implementation may run counter to both the mainstreaming process and the alignment of assistance with country priorities and systems; (iii) Climate change planning processes must be opened up to include actors from across sectors, population groups and geographical areas.
\end{abstract}

\footnotetext{
1 Introduction

Bangladesh is commonly cited as among the most vulnerable countries to the impacts of climate change (Huq and Ayers 2007; Parry et al. 2007; Harmeling 2011). The country has made significant progress in poverty reduction and economic growth in recent years, but more than 50 million people still live in poverty with weak governance and corruption is widespread, limiting the capacity to cope with and adapt to climaterelated shocks and stresses. Current disaster events can be an example to illustrate the country's vulnerability to climate change; more than 50 million people are affected by disaster events every five years. The country's long coastline is exposed to severe cyclones on an average of every three years. Annually, approximately one-quarter of the country is inundated, while the 1998 flood inundated up to 61 per cent of the country, rendering 45 million people homeless.

Nevertheless, Bangladesh has developed significant knowledge, policy and institutional defences against disaster events, evidenced by dramatic reductions in the number of fatalities during disaster events in the past two decades.
}

The occurrence of two national floods in July and Cyclone Sidr in November 2007 sparked an intensification of efforts to tackle climate change and disaster impacts in Bangladesh. This was underpinned by the recognition that climate change posed a serious threat to Bangladesh's goal of becoming a middle-income country by 2021 (GoB 2006). Nationally, the post-2007 efforts were spearheaded by the formulation by the Government of Bangladesh (GoB) of its Climate Change Strategy and Action Plan (BCCSAP) and establishment of a trust fund for its implementation to be financed by both the national government and international donors. This planning process has received considerable attention for two reasons. First, that the planning process and its implementation will determine the future sustainability of development in a highly climate-vulnerable country. Second, that Bangladesh is linked to and plays a vital role in international climate change diplomacy and politics.

The process and content of the post-2007 plans are considerably different in nature and scope 
from previous climate change-related initiatives, such as the National Adaptation Programme of Action (NAPA) that was formulated under the UN Framework Convention on Glimate Ghange (UNFCGG) in 2005. While the NAPA considered only urgent and immediate priorities for adaptation, the BCCSAP is more comprehensive and focused on medium and long-term actions through pillars that committed Bangladesh to action across the areas of the UNFCCG post2012 negotiations: long-term cooperative action on emissions reduction, adaptation, mitigation, technology development and transfer and financing. Additionally, while the NAPA primarily engaged sector-based line ministries, the BCCSAP process also drew in the more powerful Ministries of Finance, Planning and the Prime Minister's Office.

This significant shift in climate change planning was influenced by a set of transformations in ideas, knowledge, actors and incentives in the post-NAPA years. These include:

- The influence of international climate change politics over national processes;

- The growing political awareness and commitment for action on climate change in Bangladesh;

- The influence of contested ideas and knowledge around tackling climate change;

- The emergence of new actors joining with established environmentalists and their interplay in the decision-making;

- The incentives created by an expectation of significant climate change-related funding.

While there is now significant understanding of the need for transitions to low carbon and climate resilient development, there is little experience in the change process required for their delivery. A growing body of knowledge in recent years has explored policy options and change processes in industrialised and rapidly industrialising countries (Giddens 2009; Helm and Hepburn 2010; Boykoff 2010), but the political economy of building resilient development at national level in developing countries remains an area with significant knowledge gaps.

This article examines the political economy of contemporary climate change planning processes in Bangladesh. Gentring on the BCCSAP, the study links this process to related financing mechanisms, exploring the role of ideas, ideology, power configuration between actors and their incentives in shaping the BCCSAP process and content. The study is based on 60 interviews with key actors concerned in the Bangladesh climate change planning process. The research team provided all interviewees the guarantee of anonymity. These interviews were combined with a review of formal and informal documents, including government notifications, meeting minutes, formal publications, newspaper clippings and press releases. The study findings are not only beneficial for Bangladeshi policymakers, researchers and the public but also other climate-vulnerable countries pursuing similar planning processes.

\section{The BCCSAP and its development}

The BCCSAP was originally developed under the leadership of a caretaker government in Bangladesh, which came into power on 11 January 2007 and lasted until 6 January 2009. The formal process of BCCSAP formulation began in March 2008 with a first draft published in September 2008 (MOEF 2008). Following the general election in January 2009, the newly formed coalition government led by the Awami League (AL) revised and launched the current version of the BCCSAP in March 2009 (MOEF 2009). Table 1 highlights the main differences between the two drafts. Three distinct phases can be distinguished in the development of the BCGSAP, each with distinct leadership, actors and dynamics.

Phase one formally began in November 2007 when the Department of the Environment (DoE) signed a Terms of Reference with the UK Department for International Development (DFID) for a policy support grant to develop the BCCSAP. Crucially, this phase established the character of the formulation process by locating it within the environmental arena. According to DFID Bangladesh staff, the DoE was chosen because it was the main nodal point for climate change activities; the DFID and UNDP-funded Comprehensive Disaster Management Programme had previously established a Climate Change Cell within the DoE. A staff member of the Climate Change Cell was assigned to design the programme, while the Economic Relations Division (ERD) of the GoB was asked to produce a financing mechanism for implementation of the BCGSAP. A document was produced to be shared 


\begin{tabular}{|c|c|c|}
\hline Version & BCCSAP 2008 & BCCSAP 2009 \\
\hline Key drivers & $\begin{array}{l}\text { Previous technical studies and plans } \\
\text { including } 2005 \text { NAPA }\end{array}$ & $\begin{array}{l}\text { Political commitment of the Awami League } \\
\text { government }\end{array}$ \\
\hline Key principles & $\begin{array}{l}\text { (a) Wide range of funding sources } \\
\text { (b) Linking adaptation and mitigation: } \\
\text { low carbon development as part of } \\
\text { climate resilient development }\end{array}$ & $\begin{array}{l}\text { (a) Funding should be grant only } \\
\text { (b) Low carbon development without } \\
\text { compromising economic growth } \\
\text { (c) Recognising the historical responsibility of } \\
\text { developed countries }\end{array}$ \\
\hline Programme of action & $\begin{array}{l}120 \text { programmes proposed. } \\
\text { Predominantly techno-managerial } \\
\text { actions including physical infrastructure, } \\
\text { technical research and development, } \\
\text { technology development, and } \\
\text { institutional capacity. Only nine } \\
\text { programmes for human capacity } \\
\text { development }\end{array}$ & $\begin{array}{l}\text { No significant change in the distribution of } \\
\text { actions but additional programmes including } \\
\text { planned migration, investment in women's } \\
\text { capacity building and river dredging }\end{array}$ \\
\hline
\end{tabular}

with stakeholders by March 2008. The Ministry of Environment and Forests (MoEF) and a few influential climate change experts not involved in this process questioned whether the DoE had the 'mandate' and 'capacity to formulate a strategy of a multi-sectoral nature'. MoEF later assigned a group of experts to formulate the Strategy (DFID and DoE pers. comm. 2010).

Phase two is the core BCGSAP formulation process, which began in March 2008 and marked the launch of the first version of the BCGSAP in London at the 'UK-Bangladesh Climate Conference' in September 2008. GoB announced an allocation of 300 Crore Taka (US\$100m) per annum from the national budget to implement the BCCSAP, which the UK matched through a pledge of $£ 75$ million over five years. At the same time, the UK floated the idea of using a World Bank (WB)-led Multi-Donor Trust Fund (MDTF) to govern, manage and mobilise further finance. This phase saw a growth in debates and campaigns nationally and internationally over the process and content of BCCSAP, as well as the increasing involvement of the WB in the MDTF.

The final phase began when the AL-led coalition government engaged at the debate over the BCCSAP and MDTF at the beginning of 2009. The government set up a ministerial committee led by the Planning Minister to redevelop the BCCSAP, which highlighted key gaps in the document (GoB 2009). The Cabinet put together a six-member review committee comprised of
GoB representatives; two previous members involved in phase two and two new experts. The committee compiled a redrafted BCGSAP in August which the cabinet approved and renamed as the BCCSAP 2009 in October.

The proposed governance and management of the MDTF designed to finance implementation of the BSCCAP sharply divided the actors and created a dispute between GoB and donors, most notably the EU and DFID. GoB argued that it had capacity to manage the fund, while donors favoured the World Bank as a managing agency on the grounds that this would help in mobilising more funds as well as manage fiduciary risk. While these differences were pronounced, both GoB and donor views reflect an institutional ideological perspective that focuses attention on establishing adequate governance of funds as the primary route to their effective use. By contrast, the NGO and civil society organisation (CSO) campaign groups reflected a more justice-based ideology, campaigning on the issues of sovereignty, equity, access and principles of international cooperation as compensation rather than charity. (Mukta and Hossain 2008; Shamsuddoha and Chowdhury 2009; IDC 2010).

A compromise position was found at the Bangladesh Development Forum (BDF) meeting in February 2010, where the GoB 'confirmed their desire to establish a climate change multi-donor trust fund... led by the Government with the World Bank providing technical back-stopping and 
Box 1 Disputes over Bangladesh climate change trust funds

Until recently, the Bangladesh Climate Change Resilience Fund (BCGRF) was called the Multi-Donor Trust Fund (MDTF). The MDTF originated in the latter half of 2008 when the UK government pledged a grant amounting to $£ 75$ million over the next five years to implement the BCCSAP. The signed communiqué between the UK and Bangladesh governments invoked the Paris Declaration principles in aligning aid with national priorities. Since the UK's aid policy towards Bangladesh does not allow direct transfer to GoB's account, the MDTF was pursued as the mechanism to manage fiduciary risk. Since the creation of new institutions takes time, according to DFID, the WB was suggested as a fund manager. Since then, the WB's role in the MDTF has created significant national and international disputes between GoB, civil society, NGOs and donors.

The key areas of dispute over funding include:

- The GoB argued that it has the capacity for robust fiduciary management of the fund and wanted donors to transfer the fund directly to the government. The donors wanted the WB to provide the financial management of the MDTF, while the GoB wanted the WB to provide only technical back-stopping and transfer of management skills.

- Out of the US\$98 million mobilised for the MDTF until December 2008, its draft concept note allocated US $\$ 8$ million for the WB's execution (for management, project appraisal, and supervision and capacity building), which was criticised by the campaign group as 'high' and a conflict of interest.

- GoB and campaign groups argued that the WB's role in the MDTF opposed the principles of ownership and alignment enshrined in the UNFCGC and in the 2005 Paris Declaration on Aid Effectiveness.

- The GoB proposed to establish an independent, three-tier governance structure, while the donors wanted to appoint the WB as an independent trustee to the fund. The WB wanted the MDTF to be governed by the terms of the legal agreement between the WB and the donors.

- In accounting for the sources of finance, the major concern, particularly from the campaign groups, was whether the bilateral fund pledges from industrialised 'Annex 1' countries to the MDTF would be new and additional to the existing ODA commitments or not. The civil society organisations argued that the use of existing aid commitments was a breach of the financing commitment made under the UNFCGC.

fiduciary management' (Foster 2010). The development of implementation modalities will be crucial to the negotiation between these different ideological positions (see Box 1).

\section{Actors and ideology}

\subsection{Actors in the BCCSAP}

A wide range of actors and groups were involved in the different phases of the BCCSAP formulation process and subsequent debates. Interviews and documentary review for this research shows how the participation of the political parties in climate change issues remained almost nonexistent at the beginning of the BCCSAP formulation process, with no visible party positions. Only the AL included climate change in their election manifesto for the general election of 2009 (Box 2) and climate change remains at the periphery of the domestic politics.

The civil bureaucrats were a consistently powerful actor over the entire period of formulation. This is not unusual in policymaking processes, as they bear the sole responsibility in the preparation of major policies (Aminuzzaman 2002). During phase one and two, they assigned experts and approved their inputs for the BCCSAP. In phase three, they played a significant role in the negotiations with donors on the governance and management of the MDTF.

The community of experts in the BCCSAP process comprised of the country's senior economists, engineers and environmentalists. The individuals 


\section{Box 2 Climate change text from the Awami League 2009 election manifesto}

'All measures will be taken to protect Bangladesh - including planned migration abroad from the adverse effects of climate change and global warming'. (Awami League 2009 election manifesto, p. 21, para. 2)

'An integrated policy and plan will be formulated to protect the country from the adverse effects of global warming... Projects will be undertaken for river dredging, water conservation, flood control, prevention of river erosion and protection of forestry. Attempts will also be made for restoring and maintaining ecological balance. Initiatives will be taken to implement the Ganges barrage project to expand irrigation facilities, prevent salinity and to solve the problem of scarcity of sweet water in the Sundarban region'. (Awami League 2009 election manifesto, p. 10, para. 5)

Source www.albd.org/autoalbd/index.php?option =com_content\&task=view\&id $=367$ \&Itemid=1 (accessed 8 March 2011).

in this actor group formed a community through their historic engagement in the technical issues of environment, water management and poverty. Although fairly small in number and based in the capital, they played important roles in past environment-related policy and strategy-making process. They have strong views about what to do, as well as sharp differences over some policy issues, such as the effectiveness of infrastructural solutions for flood management. This group shares a common incentive, driven by a desire to retain their leadership over climate change issues, and is closely linked to international institutions. Many of them saw a 'window of opportunity' to engage themselves in this historic process as well as wanted to see their ideas reflected in the document.

The third influential set of actors is the internationally connected campaign groups. Two major groups that have played an influential role in the second and third phase of the BCCSAP process are the Equity and Justice Working Group (www.equitybd.org), which is a coalition of national NGOs, and the Oxfam-led Campaign for Sustainable Rural Livelihood (CSRL). Networked with global climate justice campaigns, they mobilised significant public opinion around climate change issues by organising national and international events involving influential politicians inside and outside the government in the UK and Bangladesh. Unlike any other policymaking process (Aminuzzaman 2002), the role of national and international NGOs was less visible in the BCGSAP planning process.

The fourth group is the community of bilateral and multilateral donors. The historic role of donors in injecting ideas in public policy has increased significantly in recent years, despite a reduction in aid as a proportion of GDP (Aminuzzaman 2002; Duncan et al. 2002; Sobhan 2002; Quibria and Ahmad 2007), with the World Bank prominent in terms of economic reforms. Among the bilateral agencies, DFID is the largest donor to Bangladesh, and provided financial assistance to GoB to formulate the BCCSAP (IDC 2010). DFID played the lead role in shaping and negotiating the role of the MDTF (UK and GoB).

Bangladesh has a well-developed and free media that played a significant role in shaping public opinion and debate over climate change issues, especially in promoting the idea that the MDTF should be managed by the government by publicising the policy positions of the campaign groups.

The direct involvement of the most vulnerable people was largely absent in the process of BCGSAP formulation (Hossain 2009; New Age 2008). Many of the key members of the drafting committee believed that the communities' views have been reflected in the BCGSAP, as it took note of the learning from the NAPA regional consultation meetings, despite the limitations of this process noted elsewhere (Huq and Khan 2006). During the second phase, such representation may be assumed through the participation of invited NGOs and members from civil society in three consultative meetings organised in Dhaka (along with academics, local and national government and donors). However, their role was limited to raising issues and commenting on the draft. 


\subsection{The role of ideology in shaping positions}

The research distilled a range of different drivers for climate change planning in Bangladesh, based on ideological belief systems that animate social and political action (see Clapp and Dauvergne 2005).

The pluralists include the bureaucrats and expert community. They assume that the liberal planning process creates an environment for all interest groups in the society to influence the planning process. As a consequence, specific measures may not be necessary to involve the most vulnerable section of the community. As a result, involvement of local NGOs was seen as a substitute for the direct involvement of vulnerable communities.

The climate justice ideology is a descendent of the trade justice ideology and is the most influential ideology shared by individuals and institutional actors within governments, campaigns, media, some of the community of experts and donors. The key interpretation of the ideology is of Bangladesh's right to new and additional international resources to tackle the causes and effects of climate change, with those for adaptation in particular regarded as 'compensation' for damages caused by emissions largely generated elsewhere (Farber 2006; Daily Star 2008a; Okereke 2010).

The leftwing ideology, although less visible, has a historical root in opposing the role of international financial institutions in domestic policymaking. Journalists in Bangladesh who raised the issues on the BCGSAP process and content in the second phase, are known as 'leftleaning'. Bangladesh had a historical presence of strong left-leaning political parties until the fall of the Soviet Union. The socialist character of AL and the ruling coalition is shaped by the joining of influential leftists in AL, as well as left parties in the coalition. Many experts interviewed by the research team believed that the coalition government's opposition to the WB role in the MDTF and the refusal of loans for climate change until 2009 was a reflection of both the leftist and climate justice ideologies. Some of the biggest contemporary campaigns, especially in relation to natural resources and energy, are organised by left political parties and intellectuals.

The faith-based drivers are found especially within the Islamic and Christian traditions. Christian ethics have heavily underpinned notions of climate justice both internationally and in Bangladesh, particularly through the NGO movement and its advocacy. While Islamist ideology has been influential in translating major policy ideas, such as education policy, land rights and women's issues in Bangladesh, they played a very limited role in the BCCSAP process.

Market liberals have been crucial in promoting the idea that a mix of grants and loans is an essential element to finance efforts to manage climate change. This ideology is shared by the multilateral development banks, government bureaucrats and community of experts. Aid effectiveness as a global standard is the most important component of the management and governance of climate change grants.

The combination of the pluralist, market liberalist, climate justice and left ideologies had an influence in raising debates throughout the BCCSAP process. As an outcome, the climate justice ideology resulted in a prolonged campaign in Bangladesh and Europe. The influence of market liberals translated into the GoB's acceptance of the WB's role in the MDTF and signing of a concessional loan agreement between GoB and WB.

\section{Contested ideas in climate change planning}

This section presents key ideas generated in the climate change planning process, analysing why and how different ideas were generated and contested.

\subsection{Specialised vs general development planning}

The Planning Commission is the central planning body in Bangladesh, responsible for macro- and micro-economic plans and policies, including the National Five Year Plan and the Annual Development Plans, while ministries are responsible for sectoral policy formulation, planning, evaluation and execution (Aminuzzaman 2002). However, Bangladesh does not have any formal process for strategy development (Chowdhury 2003). Echoing the central tenet of donor approaches (see Seballos and Kreft, this IDS Bulletin), planning experts interviewed in Bangladesh argued that mainstreaming of climate change should be achieved through the national planning process and its institutions. This is to avoid potentially increasing climate vulnerability through the development process ('maladaptation') and the 
ability to include both climatic and non-climatic factors in the planning process.

Although BCCSAP acknowledges the mainstreaming process as a means to address the multi-sectoral nature of climate change problem, its location within a sectoral ministry may have weakened its potential effectiveness in the central planning process. Interviewed experts were also concerned about the possibility that BCCSAP implementation may not go through the regular national planning appraisal, approval and financing process. This process may also potentially be duplicated, given the two different governance and management infrastructures under the National Trust Fund and the MDTF (see Box 1).

\subsection{Top-down vs bottom-up process}

The BCCSAP has been a largely specialist-driven process and without involvement of the most vulnerable communities affected by climate change (Hossain 2009; Raihan et al. 2010). The BCCSAP was finalised with three day-long workshops, separately, with government ministries, civil society members and donors, respectively. Such a process was heavily criticised by the campaign groups, media and politicians. For example, the current Finance Minister stated that 'the representation of the people who are vulnerable to climate change should be included in fund management and developing the climate change strategy paper' (Daily Star 2008b).

Experts involved claimed that this was due to the limited time available to produce the initial plan in only six months: 'The document could have been much nuanced and effective had there been more time for consultation'. This was also because the DFID finance for the development of BCCSAP did not include any resources or guidance on involving these groups in the process. The limited consultation was also justified in part because it included the consultative analysis and studies done during the NAPA preparation in 2005. The interviews also revealed that many experts and staff of donor agencies considered that community consultation would not substantially alter the content, reflecting the pluralist ideology of policymaking.

\subsection{Techno-managerial vs human capacity building}

The country's wealth of development knowledge, especially in disaster, water and the environment arena was well represented in narratives of both climate change and also what should be done to adapt to its impacts. For example, the post Hyogo disaster analysis put social and political aspect of vulnerability at the centre of policy and practice of disaster risk reduction. Although engineering solutions to disaster problems have always been controversial in Bangladesh, informed interviewees argued that the BCCSAP should have been built on the past lessons from infrastructural projects on disaster management, especially from the Flood Action Plan of the 1990s (Lewis 2010).

\subsection{Grant funding vs concessional loan}

There was considerable frustration expressed by government actors and civil society groups alike that despite political declarations, only limited climate change funding had reached Bangladesh up to 2007. Following the huge economic losses resulting from the 2007 disasters, the GoB and Bangladesh campaign groups converged around narratives of claiming compensation for damages caused by climate change. Some key officials within the GoB advocated for concessional loans, fearing that Bangladesh would not receive the adequate amount of grants (GoB 2009).

However, in the run up to the Copenhagen negotiations, Foreign Minister Dipu Moni argued that the Copenhagen conference must agree on funding grants and not loans (Daily Star 2009), while newspapers ran another story claiming that the Economic Relations Department of the Ministry of Finance was pursuing a loan-based MDTF sponsored by the WB, despite MoEF opposition on the grounds that it contradicts Bangladesh's stance with the least developed countries (LDCs) and G77 in the global climate negotiations (New Age 2008).

\subsection{World Bank vs GoB management of climate change Trust Funds}

The communique signed between the GoB and UK states, 'support will comply with the 2005 Paris Declaration on Aid Effectiveness, aligning it to a government owned plan through a Bangladesh Multi Donor Trust Fund... and the UK will continue to work with GoB and other development partners to make MDTF operational' (DFID and GoB 2008: para. 11). As outlined earlier in this article, the WB's involvement as administrator has been met with significant resistance, and a huge dispute between the government and sponsoring donors, overshadowing the discussion on the 
content and process of BCCSAP during its second and third phases.

\section{Further reflections}

The Bangladesh experience demonstrates a number of lessons for the political economy of climate change planning in both Bangladesh and other vulnerable countries.

The first lesson relates to the risk of fostering planning exceptionalism for climate change. Donor concerns around aid effectiveness and consequent creation of parallel mechanisms of planning and implementation may run counter to both the mainstreaming process and the alignment of assistance with country priorities and systems. These may lead to inefficiency and a lack of transparency and inclusion in those processes. Donors must ensure that their funding does not support such duplication, and the government must integrate climate change into regular planning and approval processes, at the same time ensuring that these are made open and transparent.

Second is the need to relate issues of equity, recognition and representation to the national context. While there has been a shift from state monopoly over planning towards a more participatory approach, a pluralist perception of representative government across actors and interest groups continues to persist among the policy elites in Bangladesh. As a result, NGO participation is often assumed to be a substitute for the involvement of vulnerable communities. In developing and implementing climate change plans, a more open and discursive process is required that permits effective representation of the wide range of stakeholders concerned.

\section{Note}

* We would like to gratefully acknowledge the anonymous interviewees who gave their time for this study, and the valuable input of A.K.M. Mamunur Rashid of the Poverty, Environment and Climate Mainstreaming (PECM) Project of the Planning Commission of Bangladesh, Dr Kazi Maruful Islam in the Department of Development Studies at Dhaka University and Dr Siddiqur Rahman in
The third lesson questions the conflicting incentives of government representatives and those pursuing an ideology of climate justice. While the BCCSAP notes in its framing of the six pillars of action that the needs of the poor and vulnerable, including women and children, will be mainstreamed into all activities (MOEF 2009: 27), this is not reinforced within the more detailed programme descriptions. The role of NGOs and civil society will be crucial in advocating developing approaches and holding government to account for a justice-based approach that targets those most vulnerable to the impacts of climate change and least responsible for its causes.

Finally, the BCCSAP process demonstrates the need for sufficient time and resources to be allocated for the design of policy, plans and programmes to tackle climate change. This would allow greater levels of dialogue and participation, as well as learning lessons from past strategy processes, especially in relation to the scaling-up of existing interventions. In particular, the large-scale infrastructural projects included in the BCGSAP should be critically examined in light of past lessons from the Flood Action Plan of the 1990s and Coastal Embankment Project of the 1960s.

This study had to deal with the challenges of an issue that is unfolding quickly. With little formal documentation, the line between facts and opinion is often blurred and further studies and dialogue are recommended in two key areas: the role and influence of business and corporate interests in the planning process; and the political economy of the specific programmes of activity recommended in the BCGSAP.

the Department of Anthropology at Jahangirnagar University. Research for this article was carried out through the Political Economy of Low Carbon Climate Resilient Development project, coordinated by IDS and funded by the UK Department for International Development (DFID). The views expressed here are the views of the authors and do not represent the views or policies of IDS, DFID, or the UK government. 


\section{References}

Aminuzzaman, S. (2002) 'Public Policy Making in Bangladesh: An Overview', Public Money and Management 2: 45-64

Boykoff, M.T. (2010) The Politics of Climate Change: A Survey, London: Routledge

Chowdhury, K. (2003) The Process of Policy and Strategy Formulation, Working Paper 020, Program Development Office for Integrated Coastal Zone Management Plan (PDO-ICZMP), Dhaka: ICZMP

Clapp J. and Dauvergne P. (2005) Paths to a Green World: The Political Economy of the Global Environment, Cambridge, MA: MIT Press

Daily Star (2009) 'Victim Nations Must get Grant, not Loan: Dipu', 10 November, www.thedailystar.net/newDesign/latest_news. php?nid=20509 (accessed 7 February 2011)

Daily Star (2008a) 'Negotiate Compensation to Face Impact of Climate Change', 18 August, www.thedailystar.net/story.php?nid $=50856$ (accessed 7 February 2011)

Daily Star (2008b) 'Climate Change Fund Management: Ensure People's Representation Speakers Urge Govt', 12 October, Dhaka, Bangladesh, www.thedailystar.net/ story.php?nid=58378 (accessed 7 February 2011)

DFID and GoB (2008) UK-Bangladesh Communiqué on Climate Change, 10 September, London, www.equitybd.org/English/Press_12-09-09/ Landon-\%20UK-Bangladesh.pdf (accessed 8 February 2011)

Duncan, A.; Sharif, I.; Landell-Mills, P.; Hulme, D. and Roy, J. (2002) Supporting the Drivers of Pro-poor Change, Dhaka: DFID Bangladesh

Farber, D.A. (2006) Basic Compensation for the Victims of Climate Change, Public Law Research Paper 954357, Berkeley: University of California

Foster, M. (2010) Bangladesh Development Forum Meeting, Daily Hansard - Written Ministerial Statements, www.publications.parliament.uk/ $\mathrm{pa} / \mathrm{cm} 200910 / \mathrm{cmhansrd} / \mathrm{cm} 100302 /$ wmstext/ 100302m0001.htm (accessed 8 February 2011)

Giddens, A. (2009) Politics of Climate Change, Cambridge: Polity Press

GoB (2009) Meeting Minutes of the Ministerial Committee Formed to Review BCCSAP, Ministry of Environment and Forest, Government of Bangladesh, Dhaka: MOEF

GoB (2006) Bangladesh Vision 2021, Dhaka: Government of Bangladesh, http://boi.gov.bd/ about-bangladesh/government-and-policies/ government-vision-2021 ? format $=$ pdf (accessed 24 December 2010)
Harmeling, S. (2011) Global Climate Risk Index 2011: Who Suffers Most from Extreme Weather Events? Weather-related Loss Events in 2009 and 1990 to 2009, Germanwatch Briefing Paper, Bonn: Germanwatch

Helm, D. and Hepburn, C. (2010) The Economics and Politics of Climate Change, Oxford: Oxford University Press

Hossain M.K. (2009) 'A Birth of a Climate Change Policy and Related Debates: Analysing the Case of Bangladesh', paper presented at Environmental Policy: A Multinational Conference on Policy Analysis an Detaching Methods, June 2009, Seoul, South Korea, www.welfareacademy.org/pubs/international/ epckdi/6.pdf (accessed 8 February 2011)

Huq, S. and Ayers, J. (2007) Critical List: The 100 Nations Most Vulnerable to Climate Change, IIED Sustainable Development Opinion, London: International Institute for Environment and Development

Huq, S. and Khan, M.R. (2006) 'Equity in National Adaptation Programs of Action (NAPAs): The Case of Bangladesh', in W.N. Adger, J. Paavola, S. Huq and M.J. Mace (eds), Fairness in Adaptation to Climate Change, Cambridge, MA: MIT Press

IDC (2010) DFID's Programme in Bangladesh, House of Commons International Development Committee, Third Report of Session 2009-2010, London: HMSO

Lewis, David (2010) 'The Strength of Weak Ideas? Human Security, Policy History and Climate Change in Bangladesh', in J-A. McNeish and J.H.S. Lie (eds), Security and Development, Oxford: Berghahn Books

MOEF (2009) Bangladesh Climate Change Strategy and Action Plan 2009, Government of the People's Republic of Bangladesh, Dhaka: Ministry of Environment and Forests MOEF (2008) Bangladesh Climate Change Strategy and Action Plan 2008, Government of the People's Republic of Bangladesh, Dhaka: Ministry of Environment and Forests

Mukta, Z.H. and Hossain, M.K. (2008) Climate Change Adaptation Financing: Managing a Transparent and Pro-poor Fund in Bangladesh, CSRL Briefing Note 1, 19, Dhaka: Centre for Sustainable Rural Livelihoods, www.csrlbd.org/pressrelease-/ doc_download/18-climate-change-adaptationfinancing (accessed 8 February 2011)

New Age (2008) 'Faces of Change. Special Issue on Climate Change', 31 May 2008, Dhaka, Bangladesh 
Okereke, C. (2010) 'Climate Justice and the International Regime', Wiley Interdisciplinary Reviews: Climate Change 1.3: 462-74

Parry, M.L.; Canziani, O.F.; Palutikof, J.P.; van der Linden, P.J. and Hanson, C.E. (eds) (2007) Climate Change 2007: Impacts, Adaptation and Vulnerability, contribution of Working Group II to the Fourth Assessment Report of the Intergovernmental Panel on Climate Change, Cambridge: Cambridge University Press Quibria, M.G and Ahmad, Shafi (2007) Aid Effectiveness in Bangladesh, Munich Personal RePEc Archive Paper 10299, http://mpra.ub.uni-muenchen.de/10299/1/ MPRA_paper_10299.pdf (accessed 28 February 2011)
Raihan, M.; Huq, J.; Alsted, G. and Andreasen, H. (2010) Understanding Climate Change From Below, Addressing Barriers from Above, Dhaka: ActionAid Bangladesh

Shamsuddoha, M. and Chowdhury, R.K. (2009) Unjustifiable Bank Domination over Climate Funds in Bangladesh, Bretton Woods Project Comment 68, November/December, www.brettonwoodsproject.org/art-565619 (accessed 8 February 2011)

Sobhan, R. (2002) Political Economy of the State and Market in Bangladesh, Dhaka: Center for Policy Dialogue 